\title{
Students' approaches to learning and perception of learning environment: A comparison between traditional and problem based learning medical curricula
}

\author{
Abdulrahman Alquliti, Ehab abd elmoneim , Nisreen albouq, Motausm aboonq, kafaf jalali, Sahal arabi, \\ Ahmad alshamrani \\ Taibah University, Medina, Saudi Arabia
}

\begin{abstract}
:
Background: Teaching and learning are fundamentally different between conventional and problem based learning (PBL) curricula. There is a transformation in the College of Medicine, Taibah University, Saudi Arabia (CMTU) from the conventional to a PBL curriculum. Aim: To compare students' approaches to learning and their perception of learning environment between conventional and PBL curricula at CMTU. Method: A cross sectional study was conducted through a self-administered questionnaire on a convenience sample from the third year undergraduate male and female medical students enrolled in both PBL and conventional curricula during the academic year 2015- 2016. Students' approaches to learning and perception of learning environment were measured using the "Approaches and Study Skills Inventory for Students (ASSIST)" and the "Dundee Ready Education Environment Measure (DREEM)" instruments, respectively. Results: A total of 101 questionnaires (49 (48.5\%) and $52(51.5 \%)$ from traditional and PBL curricula, respectively) were analyzed. When compared to conventional curriculum students, PBL curriculum students showed a significantly higher overall DREEM (136.98 \pm 21.45 vs. $111.59 \pm 27.93 ; p<0.001)$ as well as all its subscales. Significantly higher ratings for strategic approach towards learning (60.77 \pm 9.12 vs. $56.35 \pm 9.93 ; p=0.02)$ and net learning orientation (deep approach + strategic approach - surface apathetic approach; $85.60 \pm 17.32$ vs. $77.76 \pm 20.63 ; p=0.04$ ) were seen in PBL curriculum students. Conclusion: The transformation to a PBL curriculum at CMTU was accompanied by a tilt in the learning style towards a desired deep and strategic learning styles and a definite improvement in the perception of learning environment among students.
\end{abstract}

Keywords: problem based learning (PBL),College of Medicine, Taibah University(CMTU),Approaches and Study Skills Inventory for Students (ASSIST),Dundee Ready Education Environment Measure (DREEM).

\section{Introduction}

Medical curricula are designed to ensure students gain of the appropriate clinical and scientific skills. The most often practiced medical teaching method is referred to as conventional system which emphasizes the broad coverage of content areas using lecture as the starting point. Another more recent method that has gained much attention in medical education is the problem based learning (PBL), which is a constructivist model of education in which the starting point for learning is a problem or query that the learner systematically explores. In PBL, learning is viewed as a process of active knowledge building rather than passive knowledge reception ${ }^{(1)}$. Criticism directed to conventional medical curricula included overcrowding of the curriculum, over-presentation of the same subjects, the presence of non-relevant subjects ${ }^{(2,3)}$, and the lack of students participation in finalizing the curriculum; which impedes the personal growth of students ${ }^{(4)}$. On the other hand, in PBL the start by a sample clinical problem or scenario encourages brainstorming to come up with the most relevant issues essential to fully understand the subject ${ }^{(5)}$; concomitantly it helps the development of generic skills, such as problem solving, thinking ability, communication among peers, teamwork within the group, and time and information management ${ }^{(6)}$.

Since its inauguration 16 years ago, College of Medicine, Taibah University (CMTU) has adapted conventional medical curricula. In a critical analysis of the conventional curriculum at CMTU, Khoshhal and Guraya, 2013 reported a non-uniform, unharmonized, and unstandardized curriculum that is far teacher centered and information oriented ${ }^{(7)}$ and recommended program ratifications based on modern teaching strategies. Furthermore, analyses of the learning styles of undergraduate students at CMTU showed a predominance of reflectors superficial style that illustrated the need to promote self-directed learning through modifying the instructional strategies of the existing curriculum, in order to influence the learning styles of the students 
towards the desired activists and pragmatists' deep learning style ${ }^{(8)}$. CMTU introduced a modified PBL based undergraduate program starting with the newly admitted students in the academic year 2014/2015, while allowing older students to continue the conventional curriculum until they graduate.

Educational environment is one of the most important factors determining the success of an effective curriculum ${ }^{(9)}$. Ramsden and Entwistle, 1981 found that student's preferred orientation to learning was influenced by the learning environment (10). On the other hand educational strategies were shown to affect the students' perception of the learning environment ${ }^{(11,12)}$. The aim of this study was to compare the students' approaches to learning and their perception of learning environment between conventional and PBL curricula in CMTU and to explore the links between them in each curriculum. Since teaching and learning are fundamentally different between conventional and PBL curricula, we hypothesized that fundamental differences between students enrolled in conventional curriculum and PBL curriculum would be detected.

\section{Methods}

Study sitting: The study was conducted at CMTU in Al-Madinah Al-Munawwarah, Kingdom of Saudi Arabia in September 2015.

Study design: A cross sectional study was conducted.

Target Population and sample size: Target population for the study was male and female third year undergraduate students enrolled in both PBL and conventional curricula at CMTU in the academic year 2015- 2016. The conventional curriculum is a teacher-centered, discipline-based curriculum where the teachers are the main providers of information through lectures. The PBL section is a student-centred, modular system in which the curriculum is structured around weekly problems that students work through in small groups during PBL tutorial sessions and they are supported by some lectures. In both systems, lectures and tutorials are held in classrooms and practicums are held in laboratories, all within the faculty of medicine building.

Data were collected through a self-administered semi structured questionnaire which included questions on personal data (age, gender, residence, and clinical year) and previous year grade point average (GPA). The researchers of this study presented the goals of the study to the students before giving the questionnaire and a verbal consent was taken from them. It took approximately 15-20 minutes to complete the questionnaire.

Instruments: Two validated instruments were used: 1- Approaches and Study Skills Inventory for Students (ASSIST) short version ${ }^{(13)}$. It was translated to Arabic by the researchers and was used to measure student's approaches and preferences of learning (learning style; student's orientation toward learning) among students. It has four parts for measure a different aspect as follows:

a. Student's conceptions of learning. It is composed of 6 items that can be used to indicate (give score to) the two main conception of learning; i.e., reproducing knowledge and personal understanding and development.

b. Student's approaches to learning. It includes 52 items that are arranged into 13 sub-scales, which in turn are distributed under the three main approaches of learning; i.e., Deep Approach, Strategic approach, and Surface Apathetic Approach. Scores on the three main approaches are created by adding together the sub-scale scores which contribute to each approach.

c. Student's preference for teaching and assessment method. It is composed of 8 items, which are arranged into 2 sub-scales (each is a sum of four items): methods that encourage understanding (related to a deep approach), and methods that transmit information (related to a surface approach).

d. Overall student's satisfaction on his/her performance. It includes one item.

All items are rated on a 1-5 scale (5 high), with exception of the last item which is rated on 1-9 scale (9 high).

2- Dundee Ready Education Environment Measure (DREEM). The Arabic translation validated before (14) was used to measure student's perception of the learning environment. It includes 50 statements relating to a range of topics directly relevant to the education climate, all are rated on a 0-4 scale (4 high). As well as the total score, DREEM score is divided into five subscales; student perceptions of learning process (SPOLP); student perceptions of teachers (SPOT); student academic self-perceptions 
(SASP); student perceptions of atmosphere (SPOA); student social self-perceptions (SSSP).

A pilot evaluation was conducted with a small group of students to identify any possible ambiguities in the Arabic versions of the questionnaires. The results found that both questionnaires were clear.

\section{Statistical analysis}

The independent variable in this study was the curriculum type (conventional or PBL), and the dependent variables were students' approaches to studying and their perceptions of the learning environment as collected through the scales and subscales of the ASSIST and DREEM instruments. Age, sex, total GPA, previous year GPA, conception of learning, motives for studying, preferences for teaching style, overall self-rating on academic progress were treated as control variables.

Data are expressed as mean \pm standard deviation or number (percentage). To compare parameters collected through Likert scale rating between PBL and traditional curricula multivariate ANOVA was used. A 2-tailed t-test for independent samples was used to compare age, total GPA and previous year GPA. Fisher's exact test was used to compare sex. To measure the strength of association between students' approaches to studying, their perceptions of the learning environment (overall DREEM and its subscales), age, total GPA and previous year GPA Pearson's correlation coefficients (r) were calculated separately for each curricula type. Differences were considered statistically significant at $\boldsymbol{p}<0.05$. The statistical analysis was performed using the Statistical Package for Social Sciences (SPSS, IBM, and Chicago, Illinois, USA) version 16.

\section{Results}

A total of 132 (66 male and 66 female) and 157 (74 male and 83 female) students were registered in the $3^{\text {rd }}$ academic year- conventional curriculum, and the $3^{\text {rd }}$ academic year- PBL curriculum, respectively. A total of 103 (47 male and 66 female) students returned a filled questionnaire. This represented a $35.6 \%$ of total students registered in both curricula (51 $(32.5 \%)$ students from conventional curriculum and 52 (39.4\%) students from the PBL curriculum). After listwise deletion for missing survey item responses, a total of 101 valid students' questionnaires were analyzed. Of those 101 students' questionnaires analyzed, 49 (48.5\%) were from traditional curriculum and $52(51.5 \%)$ were from PBL curriculum.
Basic control characteristics were compared between both curricula (table 1). PBL curriculum students showed a significantly lower age and a significantly higher total GPA. They rated interest in the content as a motive for learning significantly higher than students in the conventional curriculum. No differences were seen in sex distribution, previous year GPA, conception of learning, achieving high grades and fear of failure as motives for learning, preferences for teaching style, or overall self-rating on academic progress.

Comparison of approach to studying (table 2) revealed a significantly higher rating for strategic approach and the net orientation among students in PBL curriculum. Failing to reach statistical significance, deep approach showed a similar trend. Interest in ideas and time management ratings were significantly higher among students in PBL curriculum. Student's perception of the learning environment (DREEM) is presented in table 3 and figure 1. The overall DREEM as well as all its subscales were significantly higher among PBL curriculum students when compare to conventional curriculum students.

Regarding Age, total GPA, previous year GPA showed any significant correlation with students' approaches to studying, or with overall DREEM or its subscales. The correlation between students' approaches to studying, and overall DREEM and its subscales are shown for both conventional and PBL curricula (table 4). The negative correlation between surface approach as well as net orientation to studying and the student perceptions of learning process increased and showed statistical significance in PBL curriculum students compared to conventional curriculum students; likewise, the correlation between surface approach and student perceptions of teachers. Deep approach correlated more strongly with student perceptions of atmosphere among PBL curriculum students. Student academic self-perceptions correlated significantly to deep approach in PBL curriculum students but not in conventional curriculum students. Student social self-perceptions lost its significant correlation with both strategic and surface approaches in PBL curriculum students. 
Table 1: Comparison of demographics, conception of learning, motives for studying, preference of teaching, and overall self-rating on academic progress between students in conventional and PBL curricula

\begin{tabular}{|c|c|c|c|}
\hline & $\begin{array}{l}\text { Conventional } \\
\text { curriculum } \\
(\mathrm{n}=49)\end{array}$ & $\begin{array}{l}\text { PBL curriculum } \\
(\mathrm{n}=52)\end{array}$ & $p$ value \\
\hline Age (years) & $21.25 \pm 0.53$ & $20.60 \pm 0.64$ & $<0.001$ \\
\hline \multicolumn{4}{|l|}{ Sex } \\
\hline Male & $20(40.8 \%)$ & $26(50.0 \%)$ & \multirow{2}{*}{0.42} \\
\hline Female & $29(59.2 \%)$ & $26(50.0 \%)$ & \\
\hline \multicolumn{4}{|l|}{ Academic performance } \\
\hline Total GPA & $4.11 \pm 0.58$ & $4.40 \pm 0.24$ & 0.003 \\
\hline Previous year GPA & $3.99 \pm 0.68$ & $3.89 \pm 0.45$ & 0.44 \\
\hline \multicolumn{4}{|l|}{ Conception of learning } \\
\hline Learning as reproducing (Reproducing knowledge) & $12.69 \pm 2.03$ & $13.13 \pm 1.58$ & 0.22 \\
\hline $\begin{array}{l}\text { Learning as transforming (Personal understanding } \\
\text { and development) }\end{array}$ & $12.59 \pm 2.35$ & $13.13 \pm 1.78$ & 0.19 \\
\hline \multicolumn{4}{|l|}{ Motives for studying } \\
\hline Interest in the content & $14.08 \pm 2.46$ & $15.58 \pm 2.14$ & 0.001 \\
\hline Achieving high grades & $15.22 \pm 2.97$ & $16.08 \pm 2.70$ & 0.13 \\
\hline Fear of failure & $15.76 \pm 3.05$ & $15.52 \pm 3.21$ & 0.70 \\
\hline \multicolumn{4}{|l|}{ Preferences for teaching style which } \\
\hline Encourages understanding & $13.16 \pm 3.71$ & $14.06 \pm 3.03$ & 0.18 \\
\hline Transmits information & $15.51 \pm 2.69$ & $14.75 \pm 3.30$ & 0.20 \\
\hline Overall self-rating on academic progress & $5.94 \pm 1.97$ & $5.96 \pm 1.31$ & 0.94 \\
\hline
\end{tabular}

Table 2: Comparison of approach to studying among students in conventional curriculum versus PBL curriculum

\begin{tabular}{|c|c|c|c|}
\hline & $\begin{array}{l}\text { Conventional } \\
\text { curriculum } \\
(\mathrm{n}=49)\end{array}$ & $\begin{array}{l}\text { PBL curriculum } \\
(n=52)\end{array}$ & $\begin{array}{l}p \\
\text { value }\end{array}$ \\
\hline Deep approach & $75.16 \pm 11.54$ & $77.77 \pm 8.73$ & 0.12 \\
\hline Seeking meaning & $15.04 \pm 2.73$ & $15.21 \pm 2.40$ & 0.73 \\
\hline Relating ideas & $15.08 \pm 2.86$ & $15.67 \pm 2.73$ & 0.29 \\
\hline Use of evidence & $15.29 \pm 2.78$ & $15.27 \pm 2.12$ & 0.97 \\
\hline Interest in ideas & $14.08 \pm 2.46$ & $15.58 \pm 2.14$ & 0.001 \\
\hline Monitoring effectiveness & $15.67 \pm 3.56$ & $16.04 \pm 2.45$ & 0.54 \\
\hline Strategic approach & $56.35 \pm 9.93$ & $60.77 \pm 9.12$ & 0.02 \\
\hline Organized studying & $13.86 \pm 2.65$ & $14.63 \pm 2.60$ & 0.14 \\
\hline Time management & $12.69 \quad 3.66$ & $14.48 \pm 3.58$ & 0.01 \\
\hline Alertness to assessment demands & $14.57 \quad 3.61$ & $15.58 \pm 2.77$ & 0.11 \\
\hline Achievement motivation & $15.22 \pm 2.97$ & $16.08 \pm 2.70$ & 0.13 \\
\hline Surface apathetic approach & $53.76 \pm 7.17$ & $52.94 \pm 8.35$ & 0.60 \\
\hline Lack of purpose & $12.08 \pm 2.80$ & $12.29 \pm 3.11$ & 0.72 \\
\hline Lack of understanding (Unrelated memorizing) & $12.92 \pm 2.60$ & $13.15 \pm 2.98$ & 0.67 \\
\hline Syllabus boundness & $13.00 \pm 3.29$ & $13.71 \pm 2.93$ & 0.25 \\
\hline Fear of failure & $15.76 \pm 3.05$ & $15.52 \pm 3.21$ & 0.70 \\
\hline Net study orientation* & $77.76 \pm 20.63$ & $85.60 \pm 17.32$ & 0.04 \\
\hline
\end{tabular}

* Net approach $=($ deep approach + strategic approach $)$ - surface apathetic approach 
Table 3: Comparison of student's perception of the learning environment (DREEM scale) among students in conventional curriculum versus PBL curriculum

\begin{tabular}{|c|c|c|c|}
\hline & $\begin{array}{l}\text { Conventional } \\
\text { curriculum } \\
(n=49)\end{array}$ & $\begin{array}{l}\text { PBL curriculum } \\
(\mathrm{n}=52)\end{array}$ & $p$ value \\
\hline Student perceptions of learning process (SPOLP) & $24.10 \pm 7.89$ & $33.87 \pm 5.73$ & $<0.001$ \\
\hline I am encouraged to participate in class & $2.14 \pm 1.59$ & $3.06 \pm 1.06$ & 0.001 \\
\hline The teaching is often stimulating & $2.27 \pm 1.09$ & $3.12 \pm 0.86$ & $<0.001$ \\
\hline The teaching is student centered & $1.47 \pm 1.26$ & $3.31 \pm 1.00$ & $<0.001$ \\
\hline The teaching helps to develop my competence & $1.88 \pm 1.15$ & $3.33 \pm 0.92$ & $<0.001$ \\
\hline The teaching is well focused & $2.84 \pm 1.07$ & $2.62 \pm 0.95$ & 0.27 \\
\hline The teaching helps to develop my confidence & $2.12 \pm 1.25$ & $3.27 \pm 0.84$ & $<0.001$ \\
\hline The teaching time is put to good use & $2.18 \pm 1.18$ & $2.52 \pm 1.16$ & 0.15 \\
\hline The teaching over-emphasizes factual learning & $1.45 \pm 0.98$ & $1.62 \pm 0.84$ & 0.36 \\
\hline I am clear about the learning objectives of the course & $2.57 \pm 1.31$ & $2.71 \pm 1.00$ & 0.54 \\
\hline The teaching encourages me to be an active learner & $1.88 \pm 1.30$ & $2.56 \pm 1.11$ & 0.006 \\
\hline Long-term learning is emphasized over short-term learning & $2.20 \pm 1.27$ & $3.17 \pm 1.00$ & $<0.001$ \\
\hline The teaching is too teacher-centered & $1.10 \pm 1.01$ & $2.60 \pm 1.16$ & $<0.001$ \\
\hline Student perceptions of teachers (SPOT) & $25.59 \pm 7.46$ & $28.77 \pm 6.38$ & 0.02 \\
\hline The teachers are knowledgeable & $2.59 \pm 1.17$ & $3.27 \pm 0.91$ & 0.002 \\
\hline The teachers are patient with the students & $2.53 \pm 1.24$ & $2.69 \pm 1.00$ & 0.47 \\
\hline The teachers ridicule the students & $2.67 \pm 1.33$ & $2.44 \pm 1.21$ & 0.36 \\
\hline The teachers are authoritarian & $1.76 \pm 1.32$ & $1.85 \pm 1.30$ & 0.72 \\
\hline The teachers have good communication skills with students & $2.39 \pm 1.04$ & $2.69 \pm 1.09$ & 0.15 \\
\hline The teachers are good at providing feedback to students & $1.94 \pm 1.18$ & $2.58 \pm 1.16$ & 0.007 \\
\hline The teachers provide constructive criticism & $2.41 \pm 1.12$ & $2.85 \pm 1.14$ & 0.05 \\
\hline The teachers give clear examples & $2.67 \pm 1.20$ & $2.98 \pm 0.92$ & 0.14 \\
\hline The teachers get angry in class & $1.86 \pm 1.21$ & $2.19 \pm 1.21$ & 0.16 \\
\hline The teachers are well prepared for their classes & $2.65 \pm 1.01$ & $2.71 \pm 1.18$ & 0.79 \\
\hline The students irritate the teachers & $2.31 \pm 1.28$ & $2.52 \pm 1.08$ & 0.38 \\
\hline Student academic self-perceptions (SASP) & $19.02 \pm 5.71$ & $22.42 \pm 4.65$ & 0.001 \\
\hline $\begin{array}{l}\text { Learning strategies that worked for me before continue to } \\
\text { work for me now }\end{array}$ & $2.35 \pm 1.28$ & $2.13 \pm 1.25$ & 0.40 \\
\hline I am confident about passing this year & $2.71 \pm 1.19$ & $2.77 \pm 1.15$ & 0.81 \\
\hline I feel I am being well prepared for my profession & $1.96 \pm 1.17$ & $3.10 \pm 0.91$ & $<0.001$ \\
\hline Last year's work was a good preparation for this year's work & $2.35 \pm 1.32$ & $2.69 \pm 1.06$ & 0.14 \\
\hline I am able to memorize all I need & $2.12 \pm 1.17$ & $2.00 \pm 1.20$ & 0.60 \\
\hline $\begin{array}{l}\text { I have learned a significant amount about empathy in my } \\
\text { profession }\end{array}$ & $2.55 \pm 0.96$ & $3.06 \pm 0.85$ & 0.006 \\
\hline My problem solving skills are being well developed & $2.45 \pm 1.08$ & $3.15 \pm 0.80$ & $<0.001$ \\
\hline $\begin{array}{l}\text { Much of what I have to learn seems relevant to a career in } \\
\text { healthcare }\end{array}$ & $2.53 \pm 1.21$ & $3.52 \pm 0.58$ & $<0.001$ \\
\hline Student perceptions of atmosphere (SPOA) & $26.51 \pm 7.54$ & $33.77 \pm 6.34$ & $<0.001$ \\
\hline The atmosphere is relaxed during teaching & $2.16 \pm 1.09$ & $3.04 \pm 1.12$ & $<0.001$ \\
\hline This school implements a good time schedule & $1.71 \pm 1.26$ & $2.25 \pm 1.34$ & 0.04 \\
\hline Cheating is a problem at this school & $2.20 \pm 1.27$ & $3.13 \pm 1.19$ & $<0.001$ \\
\hline The atmosphere is relaxed during lectures & $1.88 \pm 1.24$ & $2.52 \pm 1.15$ & 0.008 \\
\hline There are opportunities for me to develop interpersonal skills & $2.39 \pm 1.15$ & $2.94 \pm 1.02$ & 0.01 \\
\hline I feel socially comfortable in class & $2.76 \pm 1.16$ & $3.29 \pm 0.80$ & 0.008 \\
\hline The atmosphere is relaxed during seminars/tutorials & $2.06 \pm 1.20$ & $2.83 \pm 1.12$ & 0.001 \\
\hline I find the experience disappointing & $2.69 \pm 1.29$ & $2.94 \pm 1.27$ & 0.33 \\
\hline
\end{tabular}


Abdulrahman Alquliti et al.

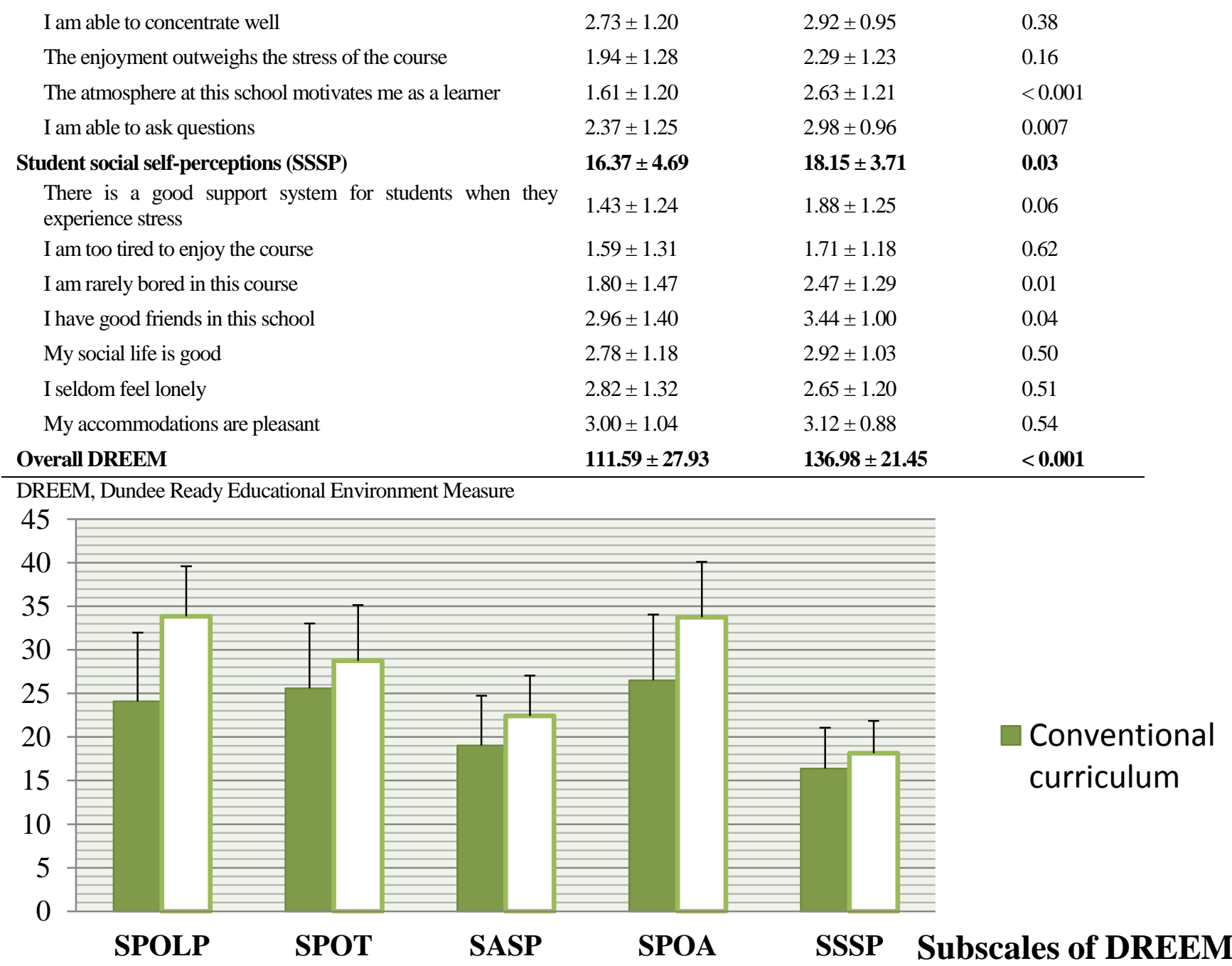

Figure 1: Subscales of the Dundee Ready Educational Environment Measure (DREEM) among students in conventional curriculum versus PBL curriculum. Differences between conventional and PBL curriculum are significant in all subscales.

SPOLP, Student perceptions of learning process; SPOT, Student perceptions of teachers; SASP, Student academic self-perceptions; SPOA, Student perceptions of atmosphere; SSSP, Student social self-perceptions

Table 4: Correlation between student's approaches to studying and perception of the learning environment in among students in conventional curriculum and PBL curriculum

\begin{tabular}{|c|c|c|c|c|c|c|c|c|c|c|c|c|}
\hline & \multicolumn{2}{|l|}{ SPOLP } & \multicolumn{2}{|l|}{ SPOT } & \multicolumn{2}{|l|}{ SASP } & \multicolumn{2}{|l|}{ SPOA } & \multicolumn{2}{|l|}{ SSSP } & \multicolumn{2}{|c|}{ Overall DREEM } \\
\hline & $\begin{array}{l}\text { Conventi } \\
\text { onal } \\
\text { curriculu } \\
\mathrm{m} \\
\mathrm{r}(\boldsymbol{p})\end{array}$ & $\begin{array}{l}\text { PBL } \\
\text { curricul } \\
\text { um } \\
\text { r }(p)\end{array}$ & $\begin{array}{l}\text { Conventi } \\
\text { onal } \\
\text { curriculu } \\
\mathrm{m} \\
\mathrm{r}(\boldsymbol{p})\end{array}$ & $\begin{array}{l}\text { PBL } \\
\text { curricul } \\
\text { um } \\
\text { r }(\boldsymbol{p})\end{array}$ & $\begin{array}{l}\text { Conventi } \\
\text { onal } \\
\text { curriculu } \\
\mathrm{m} \\
\mathrm{r}(\boldsymbol{p})\end{array}$ & $\begin{array}{l}\text { PBL } \\
\text { curricul } \\
\text { um } \\
\text { r }(\boldsymbol{p})\end{array}$ & $\begin{array}{l}\text { Conventi } \\
\text { onal } \\
\text { curriculu } \\
\mathrm{m} \\
\mathrm{r}(\boldsymbol{p})\end{array}$ & $\begin{array}{l}\text { PBL } \\
\text { curricul } \\
\text { um } \\
\text { r }(p)\end{array}$ & $\begin{array}{l}\text { Conventi } \\
\text { onal } \\
\text { curriculu } \\
\mathrm{m} \\
\mathrm{r}(\boldsymbol{p})\end{array}$ & $\begin{array}{l}\text { PBL } \\
\text { curricul } \\
\text { um } \\
\text { r }(p)\end{array}$ & $\begin{array}{l}\text { Conventi } \\
\text { onal } \\
\text { curriculu } \\
\mathrm{m} \\
\mathrm{r}(\boldsymbol{p})\end{array}$ & $\begin{array}{l}\text { PBL } \\
\text { curricul } \\
\text { um } \\
\mathrm{r}(\boldsymbol{p})\end{array}$ \\
\hline $\begin{array}{l}\text { Deep } \\
\text { approa } \\
\text { ch }\end{array}$ & $\begin{array}{l}0.18 \\
(0.22)\end{array}$ & & $\begin{array}{l}0.06 \\
(0.68)\end{array}$ & & $\begin{array}{l}0.30 \\
(0.03)\end{array}$ & & $\begin{array}{l}0.18 \\
(0.22)\end{array}$ & & $\begin{array}{l}-0.03 \\
(0.85)\end{array}$ & & & \\
\hline $\begin{array}{l}\text { Strategi } \\
\text { c } \\
\text { approa } \\
\text { ch }\end{array}$ & $\begin{array}{l}0.35 \\
(0.01)\end{array}$ & $\begin{array}{l}0.34 \\
(0.01)\end{array}$ & $\begin{array}{l}0.14 \\
(0.34)\end{array}$ & $\begin{array}{l}0.18 \\
(0.21)\end{array}$ & $\begin{array}{l}0.56 \\
(<0.001)\end{array}$ & $\begin{array}{l}0.48 \\
(<0.001 \\
)\end{array}$ & $\begin{array}{l}0.33 \\
(0.02)\end{array}$ & & $\begin{array}{l}0.34 \\
(0.02)\end{array}$ & & $\begin{array}{l}0.39 \\
(0.005)\end{array}$ & $\begin{array}{l}0.37 \\
(0.01)\end{array}$ \\
\hline $\begin{array}{l}\text { Surface } \\
\text { approa } \\
\text { ch }\end{array}$ & $\begin{array}{l}-0.33 \\
(0.02)\end{array}$ & $\begin{array}{l}-0.35 \\
(0.01)\end{array}$ & $\begin{array}{l}-0.21 \\
(0.15)\end{array}$ & & $\begin{array}{l}-0.14 \\
(0.32)\end{array}$ & & $\begin{array}{l}-0.26 \\
(0.07)\end{array}$ & & $\begin{array}{l}-0.33 \\
(0.02)\end{array}$ & & $\begin{array}{l}-0.30 \\
(0.03)\end{array}$ & \\
\hline $\begin{array}{l}\text { Net } \\
\text { orientat } \\
\text { ion }\end{array}$ & $\begin{array}{l}0.40 \\
(0.004)\end{array}$ & $\begin{array}{l}0.47 \\
(<0.001 \\
)\end{array}$ & $\begin{array}{l}0.18 \\
(0.21)\end{array}$ & $\begin{array}{l}0.32 \\
(0.02)\end{array}$ & $\begin{array}{l}0.51 \\
(<0.001)\end{array}$ & $\begin{array}{l}0.58 \\
(<0.001 \\
)\end{array}$ & $\begin{array}{l}0.36 \\
(0.01)\end{array}$ & $\begin{array}{l}0.47 \\
(<0.001 \\
)\end{array}$ & $\begin{array}{l}0.31 \\
(0.03)\end{array}$ & $\begin{array}{l}0.33 \\
(0.02)\end{array}$ & $\begin{array}{l}0.41 \\
(0.003)\end{array}$ & $\begin{array}{l}0.54 \\
(<0.001 \\
)\end{array}$ \\
\hline
\end{tabular}


r, Pearson coefficient, $\boldsymbol{P}, \boldsymbol{P}$-value; SPOLP, Student perceptions of learning process; SPOT, Student perceptions of teachers; SASP, Student academic self-perceptions; SPOA, Student perceptions of atmosphere; SSSP, Student social self-perceptions

\section{Discussion:}

This study examined the possible effects and interactions between type of curriculum, conventional or PBL, approach of studying and perception of learning environment, in the context of the newly applied PBL curriculum in CMTU. The basic conceptions of learning (what is meant by learning in the mind of students), either learning for understanding or learning for reproducing, did not show significant difference between the two curricula. This might be explainable by the fact that this inherent attribute is highly dependent on the environmental and cultural factors that did not differ between the two cohorts. Likewise, preferences for teaching style and overall self-rating on academic progress did not show any differences between the two curricula. This agrees with some published data that found no differences in self ratings in the cognitive domain between PBL and conventional curricula graduates. A possible explanation that put forward was that the clinical patient care components of both PBL and conventional curricula were conducted in similar traditional ways ${ }^{(15)}$. PBL students were significantly more interested in the content. Group works in PBL was shown to be interesting and motivating for students as they become actively involved in the work and were held accountable for their actions by group members ${ }^{(16)}$.

In regard students' approaches to studying, the results reveal that students employee all approaches when learning in both curricula. However, the extent to which the approaches are used varies. In Deep approach of learning PBL, students recorded insignificant higher scores in the subscales seeking meaning, relating ideas, use of evidence and monitoring and a significant higher score in the subscale interest of ideas. Two reviews found that PBL promoted self directed learning and thud deep learning that was also sustained ${ }^{(17,18)}$. However, other studies found little evidence for superiority of PBL in this regards ${ }^{(19)}$. PBL students record is significant higher overall score in Strategic approach of learning which include organize studying, alertness to assessment demands, achievement motivations with notable significant difference in time management for PBL students upon the conventional students .A research has shown increase workload in the PBL curriculum (20) which explain the pressure on students to improve their time management to deal with this workload. There were no significant differences in mean overall scores between the PBL and the conventional curriculum undergraduate students in accordance to Surface apathetic approach $(p=0.60)$. However, the net study orientation regarding the approach of studying between the two systems was significant ( $\mathrm{p}=0.04)$, indicating a more favorable learning style of PBL students.

In the present study, we have used DREEM in 'diagnosing' the educational environment of CMTU and making comparative analysis within the students' scores according to their curriculum (PBL and conventional). In this study, the overall DREEM was significantly higher among PBL curriculum students when compared to conventional curriculum students. Numerous published data suggest that institutions with innovative curricula are rated higher on perception of learning environment by students and scores reported from student-centered, integrated, problem-based curricula are higher than teachercentered, traditional, discipline-based curricula ${ }^{(21,}$ 23).

Although all DREEM subscales and most of its items were significantly higher in PBL students compared to conventional curriculum certain items worth noting. The large improvement in SPOLP among PBL students reflects the fact that PBL students are more encouraged to participate in class and they were motivated to be confident and to function as active learners. In SPOT, PBL students scored significantly higher on their perceptions about that teachers being knowledgeable and good at providing feedback to students that is more likely because of the lower teacher-to-student ratio in the PBL curriculum. In a previous research conducted at the same college mean and standard deviation of female students SPOT was $24.63 \pm 4.91^{(24)}$, which did not differ from the current rating in conventional curriculum $(25.59 \pm 7.46)$, whereas it increased to $28.77 \pm$ 6.38 for the PBL curriculum reflecting a major impact of the PBL curriculum in increasing the student perception of teachers. As regards SASP, it is notable that PBL students felt more linked to their coming career by rating their perception about being prepared for their profession, learning a significant amount about empathy in the 
profession and the relevance of what they learn to a career in healthcare higher than conventional curriculum students. Although students in PBL curricula felt that their problem solving skills are being well developed more than conventional curriculum students, long term effect of this need to be seen as data in the literature are conflicting regarding clinical diagnostic competencies of graduates from PBL system ${ }^{(25,26)}$. Despite that both curricula are delivered in the same place and with nearly the same staff, PBL curricula students perceived the atmosphere as more relaxed and motivating than conventional curriculum students. On the other hand, both curricula students rated the support given by the medical school to students in situations they experience stress is very low. In general, the correlations between approach to studying and perception of learning environment were different as regard significance and strength between conventional and PBL curricula.

\section{Conclusion}

The transformation to a PBL curriculum at CMTU was accompanied by a tilt in the learning style towards a desired deep and strategic learning styles and a definite improvement in the perception of learning environment among students. PBL curriculum generated a more stimulating and challenging educational environment in CMTU.

\section{References}

1. Evensen DH, Hmelo CE(2004): editors. Problem-based learning: a research perspective on learning interactions. Mahwah (NJ): Lawrence Erlbaum Associates. https://link.springer.com/article/10.1023/B:ED PR.0000034022.16470.f3

2. Al-Gindan YM, Al-Sulaiman AA, AlFaraidy A (2000): Undergraduate curriculum reform in Saudi medical schools: Which direction to go? Saudi Med J 2004; 21: 324-326. https://europepmc.org/abstract/med/1153381 0

3. Elfaki EA(2004): Undergraduate curriculum reform in Saudi medical schools. Saudi Med J., 21: 988.

4. Aspy D, Roebuck F(2004): Our research and our findings. In: Rogers CR. http://www.ibe.unesco.org/sites/default/files/r ogerse.PDF

5. Ahmed I. Albarrak, Rafiuddin Mohammed, Abalhassan MF, Almutairi NK (2013): Academic satisfaction among traditional and problem based learning medical students. Saudi Med J ., 34:11 .

6. Murray-Harvey R, Curtis D, Cattley G, Slee P(2004 ): Enhancing Learners' Generic Skills through Problem based Learning. https://www.researchgate.net/publication/24053 2700_Enhancing_Teacher_Education_Students' _Generic_Skills_Through_Problembased_Learning

7. Khoshhal KI, Guraya SS (2012): Time to change the undergraduate curriculum at the College of Medicine, Taibah University in terms of SPICES model. Br J Edu., 2: 419-429

8. Guraya SS, Guraya SY, Habib FA, Khoshhal KI (2014): Learning styles of medical students at Taibah University: Trends and implications. J Res Med Sci.,19:1155-62.

9. Bassaw $B$, Roff $S$, McAleer $S$, Roopnarinesing S, Lisle JD, Teelucksing S, Gopaul S(2004): https://oncall.neurocriticalcare.org/home?gcli d=EAIaIQobChMI2sep6IeZ4AIVFpzVCh3r sQplEAAYASAAEgK_1PD_BwE

10. Ramsden P, Entwistle NJ (2007): Effects of academic departments on student's approaches to studying. Br J. Edu Psych., 51:368-383.

11. Roff S, McAleer S, Harden RM, AlQahtani M, Ahmed AU, Deza $\mathrm{H}$ et al.(2004): Development and validation of the Dundee Ready Education Environment Measure (DREEM). Med Teach., 19: 295299.

12. Wood DF (2004): ABC of learning and teaching in medicine: Problem based learning. BMJ., 326:328-330.

13. Tait H, Entwistle N, McCune V (2004): Improving student learning: Improving students as learners. https://pdfs.semanticscholar.org/a536/cf4add2 d45ea4b0625fd86e5bdfd17270f93.pdf

14. AL-Qahtani MF (2004): Approaches to study and learning environment in medical schools with special reference to the gulf countries.

https://www.medicalacademy.org/portal/

15. Beachey WD (2008): A Comparison of Problem-Based Learning and Traditional Curricula in Baccalaureate Respiratory Therapy Education. https://pdfs.semanticscholar.org/f92c/5541d5 8517d459cdc0a8d8fc720c2926605b.pdf

16. Speaking of Teaching Winter (2004): https://arrs.org/uploadedFiles/ARRS/Life_Lo 
ng_Learning_Center/Educators_ToolKit/ST

N_problem_based_learning.pdf

17. Newman M (2004): A pilot systematic review and metaanalysis on the effectiveness of problem based learning. https://www.researchgate.net/publication/242 422073_A_Pilot_Systematic_Review_and_ Meta-

Analysis_on_the_Effectiveness_of_ProblemBased_Learning

18. Norman GR, Schmidt HG(2005): The psychological basis of problem-based learning: a review of the evidence. Acad Med., 67: 557-565.

19. Spencer JA, Jordan RK (2009): Learner centred approaches in medical education. BMJ., 318: 1280-1283.

20. Donner RS, Bickley H (2006): Problembased learning: an assessment of its feasibility and cost. Hum Path., 21: 881-5.

21. Demiroren M, Palaoglu O, Kemahli S, Ozyurda F, Ayhan IH (2008): Perceptions of students in different phases of medical education of educational environment: Ankara University Faculty of Medicine. Med Educ Online, 13:8.
22. Zawawi AH, Elzubeir M (2012): Using DREEM to compare graduating students' perceptions of learning environments at medical schools adopting contrasting educational strategies. Med Teach., 34:S2531.

23. Edgren G, Haffling AC, Jakobsson U, McAleer S, Danielsen N(2010): Comparing the educational environment (as measured by DREEM) at two different stages of curriculum reform. Med Teach., 32:e233e238.

24. Makhdoom N (2009): Assessment of the Quality of Educational Climate During Undergraduate Clinical Teaching Years in the College of Medicine, Taibah University. J Taibah Uni Med Sci ., 4: 42-52

25. Vernon DT, Blake RL(2005): Does problem-based learning work? A metaanalysis of evaluative research. Acad Med ., 68: 550-563.

26. Beachey WD(2007): A comparison of problem-based learning and traditional curriculum In baccalaureate respiratory therapy education. Respiratory care , 52: 1497-1506 . 